\title{
REGULARARTICLE \\ STUDIES ON THE OCCURRENCE AND POPULATION DISTRIBUTION OF NEMATODES WITH YAM (DIOSCOREA ROTUNDATA POIR) TUBERS IN BENUE STATE, NIGERIA
}

\author{
V. ISEGBE, M. A. HABIB, S. SOLOMON*
}

Nigeria Agricultural Quarantine Service, Abuja. Nigeria

\begin{abstract}
Yam (Dioscorea spp) nematodes have been variously reported to reduce tuber yield and quality worldwide. In the present study, a survey was done to estimate types, frequency and population density of nematodes associated with yam tubers at each of the Local Government headquarters and two villages in Benue state of Nigeria. A total of 250 yam tubers were sampled randomly in the survey markets between April and May, 2017. Each yam sample was processed by peeling the periderm (oneinch-thick) out of which a $10 \mathrm{~g}$ sub-sample tuber was separately put in a blender with some quantity of water and macerated at low speed for 15 seconds. Plant-parasitic nematodes were recovered from the yam tubers using a modified extraction tray method. Five nematode species were found in association with yam tubers as follows: Scutellonema bradys, Meloidogyne spp, Pratylenchus spp, Rotylenchulus spp and Tylenchus spp. Scutellonema bradys was the most ubiquitous, occuring at a 100\% frequency rating in all the samples while Meloidogyne spp, Pratylenchus spp, Rotylenchulus spp and Tylenchus spp. were $29.60 \%, 16.80 \%, 8.80 \%$ and $4.80 \%$ respectively. Though the study revealed that Rotylenchulus spp and Tylenchus spp. were poor parasites of yam tubers, yet there was a widespread distribution of Scutellonema bradys, Meloidogyne spp and Pratylenchus spp on yam tubers in Benue State of Nigeria, thus control of plant-parasitic nematodes is encouraged for improved tuber quality.
\end{abstract}

Keywords: Yam nematodes, Markets, Nigeria

\section{INTRODUCTION}

Yam (Dioscorea spp) is a staple food crop in Nigeria. There are four main varieties widely cultivated in the country [7]. Large production of the yam crop is in West Africa and out of that, Nigeria is the largest producer and Ghana and Cote d'Ivoire follows Nigeria [19]. Among the world's root crops, yam is the second most used one [26]. The rise in yam consumption in the world today is due to its high nutritional value. Yam is rich in many nutrients and also have medicinal properties [18]. The crop is also used for cultural events and the harvest is always celebrated annually by some tribes in Nigeria [24]. The set standard for exportable crops including yam is necessary to be followed by stakeholders in order to raise the quality of yam export to internationally acceptable level. For example, as far back as 2000, Jamaica's yam export industry was valued at 15 million dollars and serves as source of revenue for the 15,000 small farmers [18].

Despite above listed advantages of yam to human health, economic, cultural and social benefits, the damage by agents like plant-parasitic nematodes is a major threat to this crop in all yam producing countries throughout the world $[8,10,30,2,14,23,21,7]$. In West Africa, [16] and in Central America [1] the extent of damage is high. Meloidogyne sp. type causes losses after harvest [12] there are different factors enhance the spread of nematodes in Nigeria, like a suitable a host [3].

In a bid for Nigeria Agricultural Quarantine Service (NAQS) to carry out one of her functional objectives which is to facilitate international trade in agricultural products by enforcing compliance with World Trade Organization (WTO), Sanitary and Phytosanitary (SPS) standards, a survey was carried out for yam's associated nematodes in the State with a view to controlling them for safe export and preventing postharvest losses.

\section{MATERIALS AND METHODS}

The survey was carried out in Benue State, North Central geopolitical zone of Nigeria between April and May 2017. All the headquarters of Local Government Areas of the State and two prominent villages (Obode Obi Ijegwu Ainu and Daudu) where their production crop is majorly yam were visited for collection of samples of yam tubers. There are twenty-three Local Government Areas in Benue state. In each headquarters of Local Government Areas and two major yam producing villages, ten yam tubers were

\section{Received 18 October 2017; Accepted 19 December 2017 \\ *Corresponding Author \\ S. Solomon}

Nigeria Agricultural Quarantine Service, Abuja. Nigeria

Email: solomonpqs@yahoo.com

(This article is open access and licensed under the terms of the Creative Commons Attribution License (http://creativecommons.org/licenses/by/4.o/) which permits unrestricted, use, distribution and reproduction in any medium, or format for any purpose, even commercially provided the work is properly cited. Attribution - You must give appropriate credit, provide a link to the license, and indicate if changes were made. 
sampled from an open market. This made a total of two hundred and fifty (250 tubers) samples in the entire state. Samples (yam tubers) from each market were pooled and sealed in plastic bags and protected from the sun [26]. The samples were properly labelled and taken to Nematology Research Laboratory of the Nigeria Agricultural Quarantine Service (NAQS), Moor Plantation, IbadanNigeria for analysis and identification of plant parasitic nematodes. The coverage of the state surveyed is shown in fig. 1 while The Geographic Information System (GIS) was used to indicate coordinate of each market where nematodes on the sampled yams were intercepted (fig. 2).

In the laboratory, every yam tuber collected was freed of soil, washed under a gentle stream of cool tap water and mopped dry. Each yam was processed by peeling the periderm (oneinch-thick) with a knife and cut transversely with scissors into about 1-2 cm pieces, mixed carefully and $10 \mathrm{~g}$ sub-sample was weighed out of the bulk sample per tuber and assayed for nematode using the Whitehead and Hemming [31] and identified [15, 17, 22] as described previously [4].

\section{RESULTS}

\section{Nematode species isolated from yam tubers}

Five species of parasitic nematodes were identified and recorded in association with yam tubers from Benue state of Nigeria. They include; Scutellonema bradys, Meloidogyne spp, Pratylenchus spp, Rotylenchulus spp and Tylenchus spp. (Plate 1(a-e)). The occurrence and widespread distribution of these nematode species on yam tubers in Benue State surveyed is described in table 2 while the occurrence and widespread distribution of these nematode species on yam tubers recovered from each market surveyed in Benue State of Nigeria is described in Tables 3 and 4.

\section{Population density of nematode species associated with yam tubers}

The population densities are described in table 2 and 3 . Scutellonema bradys (71.81\%) and Rotylenchulus spp and Tylenchus spp were recorded in relatively low from the tuber samples.

\section{Frequency of occurrence of nematodes from yam tubers samples}

Scutellonema bradys (100 \%), Meloidogyne spp (29.60 \%), Pratylenchus spp (16.80 \%), Rotylenchulus spp (8.80 \%) and Tylenchus spp (4.80 \%) were recorded (fig. 3).

\section{DISCUSSION}

The survey revealed a large diversity and population of Plant-Parasitic Nematodes (PPN) found in association with the yam tubers in Benue state of Nigeria. The result agree with earlier reports by [24] in which seven species of plant-parasitic nematodes associated with yam tubers from various countries were identified. The nematode species that were reported as important pest of yam tubers include; Scutellonema, Meloidogyne, Pratylenchus, Paratrichodorous, Rotylenchulus, Radopholus and Aphelenchoides.

Nematodes like Scutellonema bradys, Meloidogyne spp and Pratylenchus spp attack yam in many countries [24]. Estimates of the damaging potentials for Pratylenchus coffeae indicate that where the number of individuals in soil exceeds 600 per plant of Dioscorea rotundata [13]. Yields of yams severely infested with $M$. arenaria can be reduced by 24-80 \% in Chlna [20] while population of $M$. incognita as low as 100 juveniles per plant are said to reduce tuber yields of $D$. rotundata in India [25].

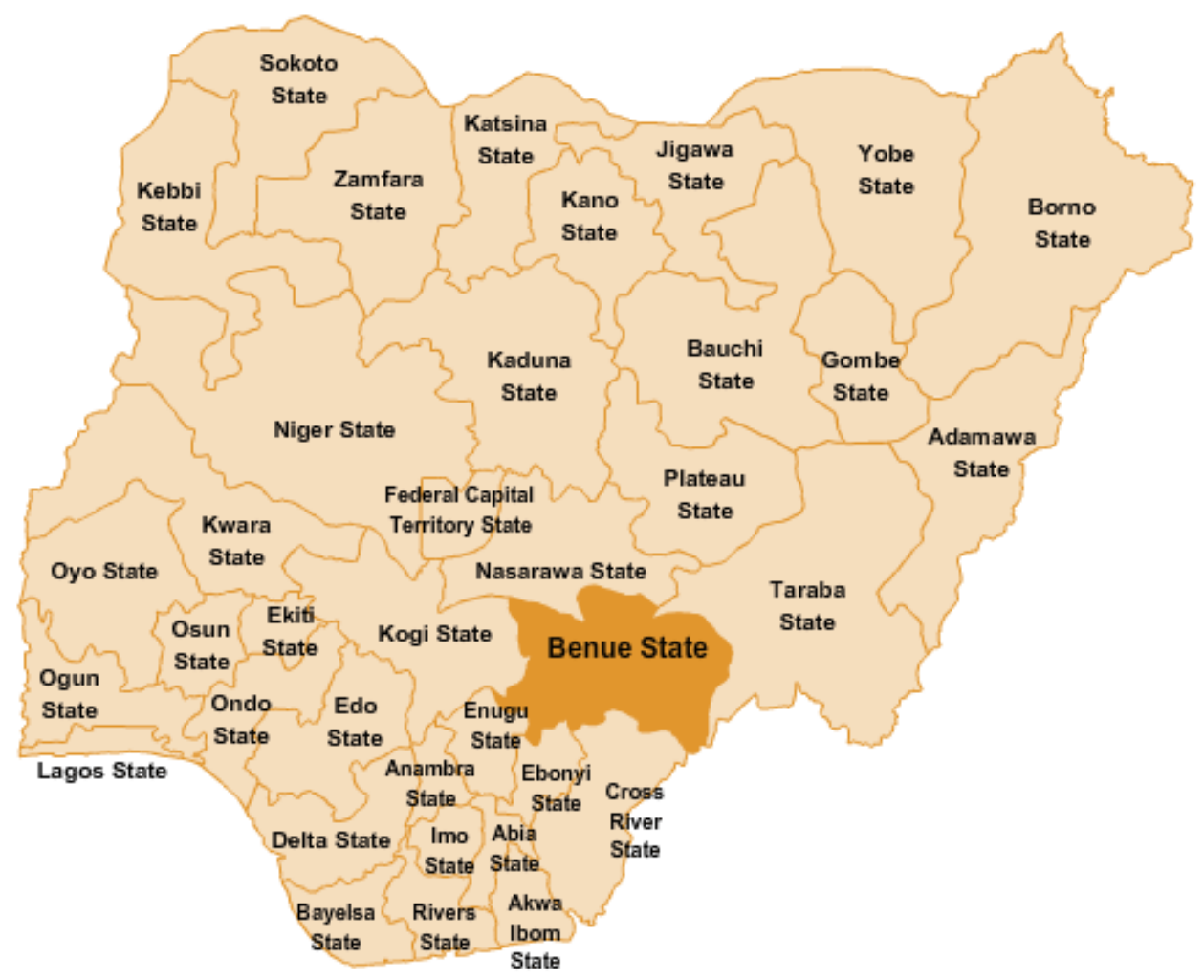

Fig. 1: Map of Nigeria showing the surveyed state for yam nematodes 


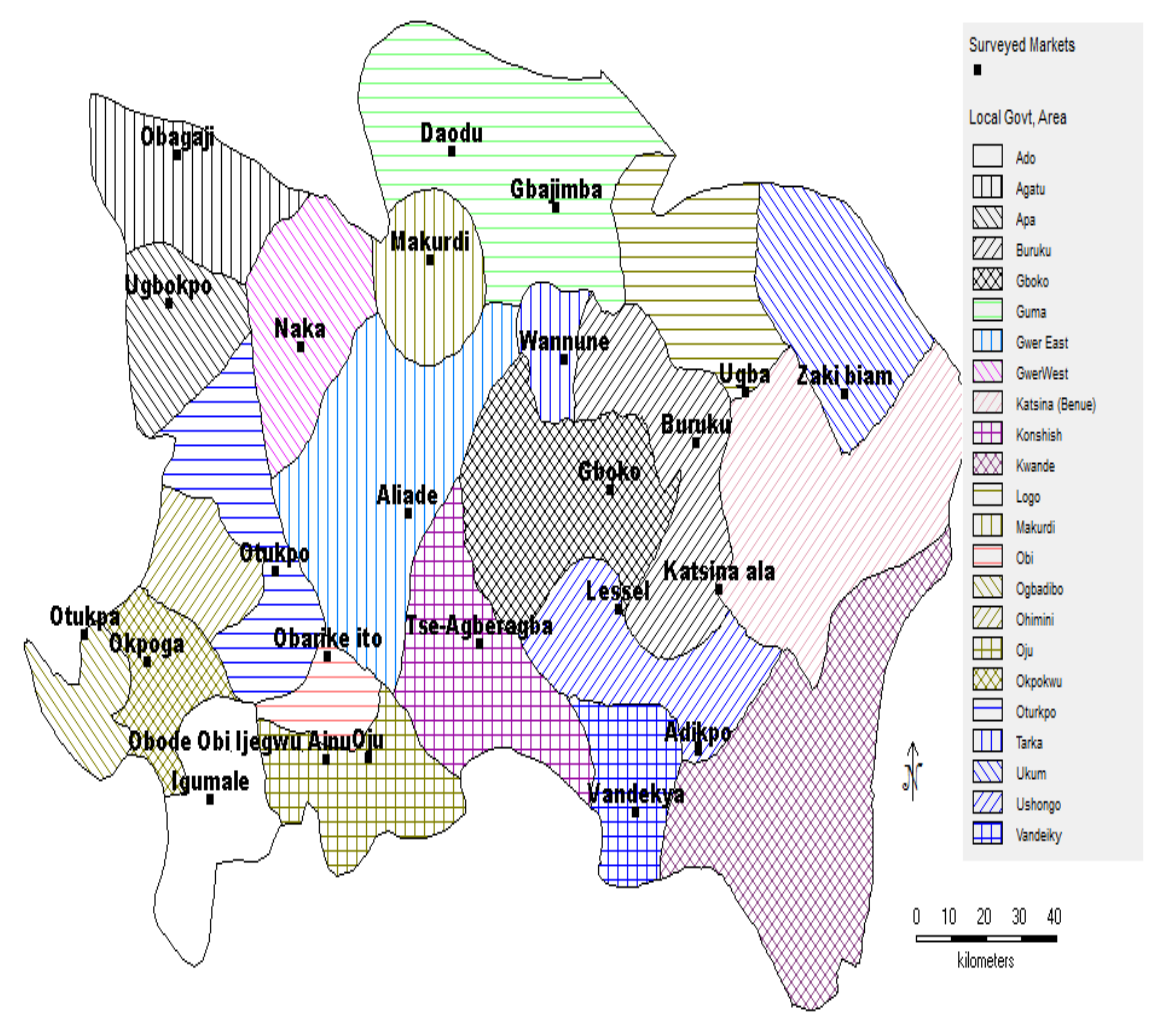

Fig. 2: survey markets in Benue State, Nigeria

In this study, survey was carried out in April when yam tubers must have been harvested and stored for a long period of time which might increase nematode species [30] as temperatures of $24-31{ }^{\circ} \mathrm{C}$ can increase yam nematode populations. Other factors that could have contributed to the widespread distribution of these nematodes on yam tubers include planting of nematode infested seed tubers and other environmental factors such as soil type as well as the presence of a suitable alternate host [4].

In Nigeria, yams usually propagate from tubers [10] and thus the risk of dissemination by this means is greater and can act as inoculum [24] for the spread. The type of soil also a determining factor for nematodes $[9,28,29]$. The cumulative effect of the damage caused by the feeding habit of these nematodes could have a negative impact on the plant vigour thereby constituting serious impediments to the quality and yield of yams which is the ultimate to farmers [5]. Due to the insidious nature of damage caused by Plant-Parasitic Nematodes (PPN), farmers and marketers are in most cases not aware of them and often times do not control nematodes on the field and store respectively thus quality decline becomes inevitable.

Awareness programmes should therefore be created to sensitize yam marketers on damage potential and the need to embark on effective management strategies on the yams in store in order to maximise market price. It is also imperative that farmers plant resistant varieties and avoid spread of PPN. Efficient regulatory measures and plant quarantine services could also help prevent the spread of such plant-parasitic nematodes from infested to uninfested farmlands.

There is a widespread distribution of plant-parasitic nematodes associated with yam tubers in Benue State of Nigeria, thus nematode control is recommended in order to improve crop quality and yield. 


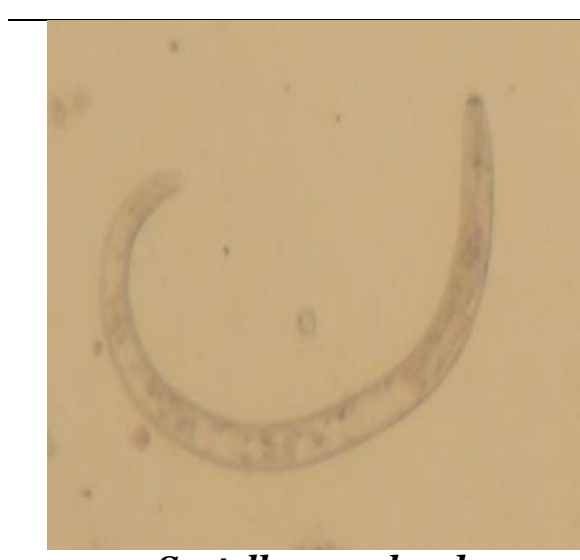

a. Scutellonema bradys

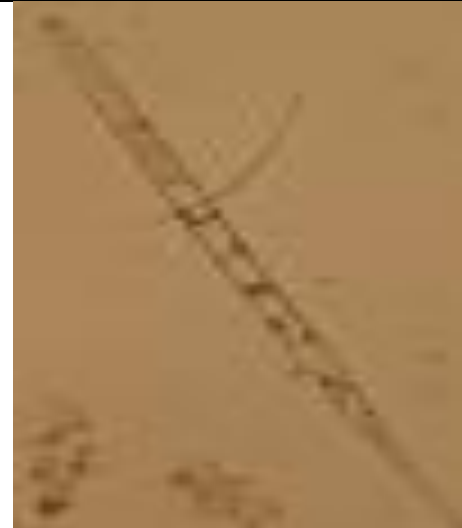

b. Meloidogyne spp.

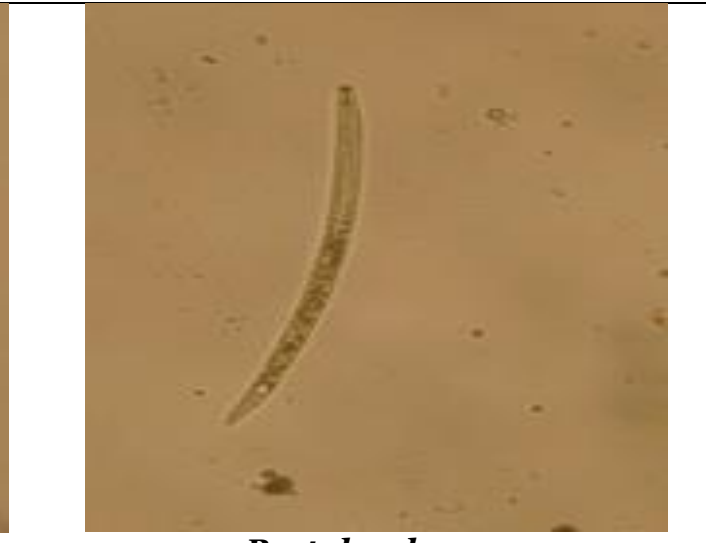

c. Pratylenchus spp.

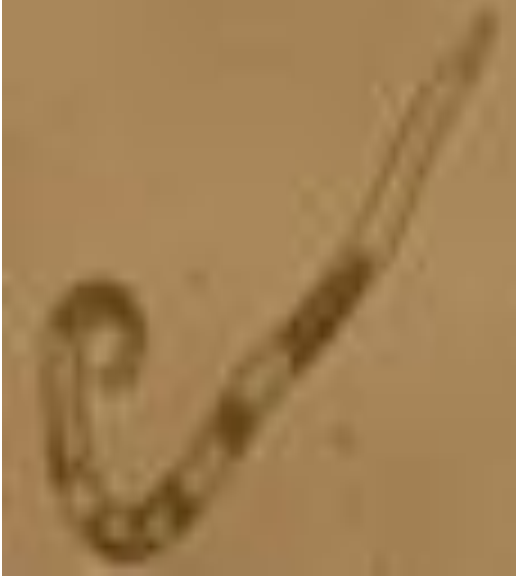

d. Rotylenchulus spp.

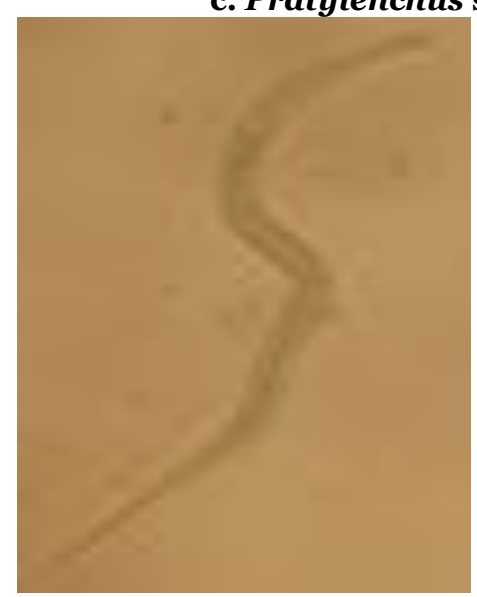

e. Tylenchus spp

Plate 1: Micrographs of parasitic nematodes found on yam tubers in Benue state of Nigeria during a market survey in 2017 (X60)

Table 1: Occurrence of Nematode species recovered from yam tubers in the Headquarters of each Local Government Area and two prominent villages of the Benue State in Nigeria

\begin{tabular}{|c|c|c|c|c|c|}
\hline \multicolumn{6}{|l|}{ Nematode species } \\
\hline Surveyed market & $\begin{array}{l}\text { Scutellonema } \\
\text { bradys }\end{array}$ & $\begin{array}{l}\text { Meloidogyne } \\
\text { spp }\end{array}$ & $\begin{array}{l}\text { Pratylenchus } \\
\text { spp }\end{array}$ & $\begin{array}{l}\text { Rotylenchulus } \\
\text { spp }\end{array}$ & $\begin{array}{l}\text { Tylenchus } \\
\text { spp }\end{array}$ \\
\hline Gboko & + & + & + & + & + \\
\hline Lessel & + & - & + & '- & - \\
\hline Vandeikya & + & + & - & - & - \\
\hline Adikpo & + & + & + & - & + \\
\hline Katsina ala & + & - & + & + & - \\
\hline Zaki Biam & + & + & + & - & - \\
\hline Ugba & + & + & - & + & - \\
\hline Buruku & + & + & + & - & + \\
\hline Tse-Agberagba & + & + & + & + & - \\
\hline Aliade & + & + & - & + & - \\
\hline Naka & + & + & + & + & - \\
\hline Ugbokpo & + & - & + & + & - \\
\hline Obagaji & + & + & + & - & - \\
\hline Idekpa & + & + & + & - & - \\
\hline Otukpa & + & + & - & + & - \\
\hline Okpoga & + & + & + & - & + \\
\hline Otukpo & + & + & + & - & + \\
\hline Igumale & + & + & + & + & - \\
\hline Oju & + & + & + & - & - \\
\hline Obarike Ito & + & + & + & + & - \\
\hline Makurdi & + & - & + & - & + \\
\hline Gbajimba & + & + & + & + & - \\
\hline Obode Obi Ijegwu & + & + & - & + & - \\
\hline Ainu & & & & & \\
\hline Daudu & + & + & - & + & - \\
\hline Wannune & + & + & + & + & + \\
\hline
\end{tabular}


Table 2: Population density of nematode species recovered from yam tubers in Benue State, Nigeria

\begin{tabular}{lllll}
\hline $\begin{array}{l}\text { Nematode } \\
\text { species }\end{array}$ & $\begin{array}{l}\text { Occurrence/250 } \\
\text { samples }\end{array}$ & $\begin{array}{l}\text { Frequency } \\
\text { occurrence \% }\end{array}$ & $\begin{array}{l}\text { Population/10 g } \\
\text { tuber }\end{array}$ & $\begin{array}{l}\text { Nematode } \\
\text { population \% }\end{array}$ \\
\hline $\begin{array}{l}\text { Scutellonema } \\
\text { bradys }\end{array}$ & 250 & 100 & 2002 & 71.81 \\
$\begin{array}{l}\text { Meloidogyne spp } \\
\text { Pratylenchus spp }\end{array}$ & 74 & & & 17.48 \\
$\begin{array}{l}\text { Rotylenchulus spp } \\
\text { Tylenchus spp }\end{array}$ & 22 & 29.6 & 487 & 8 \\
TOTAL & 12 & 16.8 & 223 & 2.04 \\
\hline
\end{tabular}

\% Frequency of Occurrence is expressed as a percentage of the total number of samples examined $(\mathrm{n} / \mathrm{N} \mathrm{X} \mathrm{100),} \mathrm{Where} \mathrm{n}=$ Number of time a nematode occurs and $\mathrm{N}=$ the sample size. Sample size $(\mathrm{N})=250$

Table 3: Population density of nematode species associated with yam tubers in the survey market of Benue State in Nigeria

\begin{tabular}{|c|c|c|c|c|c|c|c|c|c|c|c|}
\hline \multicolumn{12}{|c|}{ Nematode species } \\
\hline \multirow[t]{2}{*}{ Survey market } & \multicolumn{2}{|c|}{$\begin{array}{l}\text { Scutellonema } \\
\text { bradys }\end{array}$} & \multicolumn{2}{|c|}{$\begin{array}{l}\text { Meloidogyne } \\
\text { spp. }\end{array}$} & \multicolumn{2}{|c|}{$\begin{array}{l}\text { Pratylenchus } \\
\text { spp. }\end{array}$} & \multicolumn{2}{|c|}{$\begin{array}{l}\text { Rotylenchulus } \\
\text { spp }\end{array}$} & \multicolumn{3}{|c|}{$\begin{array}{l}\text { Tylenchus } \\
\text { spp }\end{array}$} \\
\hline & Pop. & \% Pop. & Pop. & $\begin{array}{l}\text { \% } \\
\text { Pop. }\end{array}$ & Pop. & \% Pop. & Pop. & $\begin{array}{l}\text { \% } \\
\text { Pop. }\end{array}$ & Pop & $\begin{array}{l}\text { \% } \\
\text { Pop. }\end{array}$ & $\begin{array}{l}\text { Tot } \\
\text { al }\end{array}$ \\
\hline Wannune & 83 & 74.77 & 19 & 17 & 5 & 4.5 & 2 & 1.8 & 2 & 1.8 & 111 \\
\hline Gboko & 68 & 61.26 & 30 & 27 & 10 & 9.01 & 1 & 0.9 & 2 & 1.8 & 111 \\
\hline Lessel & 93 & 93 & - & - & 7 & 7 & - & - & - & - & 100 \\
\hline Vandeikya & 104 & 80 & 26 & 20 & - & - & - & - & - & - & 130 \\
\hline Adikpo & 74 & 68.52 & 23 & 21 & 9 & 8.33 & - & - & 2 & 1.85 & 108 \\
\hline Katsina ala & 64 & 70.33 & - & - & 22 & 24.2 & 5 & 5.5 & - & - & 91 \\
\hline Zaki Biam & 51 & 64.56 & 18 & 23 & 10 & 12.7 & & & & & 79 \\
\hline Ugba & 91 & 77.78 & 20 & 17 & - & - & 6 & 5.1 & - & - & 117 \\
\hline Buruku & 77 & 63.11 & 28 & 23 & 14 & 11.5 & - & - & 3 & 2.46 & 122 \\
\hline Tse-Agberagba & 69 & 58.97 & 34 & 29 & 11 & 9.4 & 3 & 2.6 & - & - & 117 \\
\hline Aliade & 70 & 72.16 & 21 & 22 & - & - & 2 & 2.1 & 4 & 4.12 & 97 \\
\hline Naka & 68 & 55.28 & 29 & 24 & 21 & 17.1 & 5 & 4.1 & - & - & 123 \\
\hline Ugbokpo & 80 & 77.67 & - & - & 16 & 15.5 & 7 & 6.8 & - & - & 103 \\
\hline Obagaji & 85 & 71.43 & 13 & 11 & 21 & 17.7 & - & - & - & - & 119 \\
\hline Idekpa & 81 & 69.23 & 22 & 19 & 14 & 12 & - & - & - & - & 117 \\
\hline Otukpa & 101 & 82.11 & 19 & 15 & - & - & 3 & 2.4 & & & 123 \\
\hline Okpoga & 75 & 68.81 & 25 & 23 & 8 & $7 \cdot 34$ & - & - & 1 & 0.92 & 109 \\
\hline Otukpo & 80 & 66.12 & 32 & 26 & 6 & 4.96 & - & - & 3 & 2.48 & 121 \\
\hline Igumale & 92 & 72.44 & 27 & 21 & 5 & 3.94 & 3 & 2.6 & - & - & 127 \\
\hline Oju & 84 & 76.36 & 17 & 15 & 9 & 8.18 & - & - & - & - & 110 \\
\hline Obarike Ito & 79 & 64.75 & 24 & 20 & 10 & 8.2 & 9 & 7.4 & - & - & 122 \\
\hline Makurdi & 90 & 85.71 & - & - & 13 & 12.4 & - & - & 2 & 1.9 & 105 \\
\hline Gbajimba & 86 & 70.49 & 21 & 17 & 12 & 9.84 & 3 & 2.5 & - & - & 122 \\
\hline $\begin{array}{l}\text { Obode Obi Ijegwu } \\
\text { Ainu }\end{array}$ & 76 & 81.72 & 16 & 17 & - & - & 1 & 1.1 & - & - & 93 \\
\hline Daudu & 81 & 72.97 & 23 & 21 & - & - & 7 & 6.3 & - & - & 111 \\
\hline
\end{tabular}

Sample size $=250$, Pop. $=$ Population 
Table 4: Frequency of occurrence of nematode species associated with yam tubers in the survey market of Benue State in Nigeria

\begin{tabular}{|c|c|c|c|c|c|c|c|c|c|c|}
\hline \multicolumn{11}{|c|}{ Nematode species } \\
\hline \multirow[t]{2}{*}{ Survey market } & \multicolumn{2}{|c|}{$\begin{array}{l}\text { Scutellonema } \\
\text { bradys }\end{array}$} & \multicolumn{2}{|c|}{ Meloid spp } & \multicolumn{2}{|c|}{ Prat spp. } & \multicolumn{2}{|c|}{ Roty spp. } & \multicolumn{2}{|c|}{ Tylenchus spp } \\
\hline & Freq. & \% Freq. & $\begin{array}{l}\text { Freq } \\
\text {. }\end{array}$ & $\begin{array}{l}\text { \% } \\
\text { Freq. }\end{array}$ & $\begin{array}{l}\text { Freq } \\
\text {. }\end{array}$ & $\begin{array}{l}\text { \% } \\
\text { Freq. }\end{array}$ & $\begin{array}{l}\text { Freq } \\
\text {. }\end{array}$ & $\begin{array}{l}\% \\
\text { Freq. }\end{array}$ & $\begin{array}{l}\text { Freq } \\
\text {. }\end{array}$ & $\begin{array}{l}\% \\
\text { Freq. }\end{array}$ \\
\hline Wannune & 10 & 100 & 4 & 40 & 1 & 10 & 2 & 20 & 1 & 10 \\
\hline Gboko & 10 & 100 & 3 & 30 & 3 & 30 & 1 & 10 & 1 & 10 \\
\hline Lessel & 10 & 100 & - & - & 2 & 20 & - & - & - & - \\
\hline Vandeikya & 10 & 100 & 4 & 40 & - & - & - & - & - & - \\
\hline Adikpo & 10 & 100 & 3 & 30 & 2 & 20 & - & - & 1 & 10 \\
\hline Katsina ala & 10 & 100 & - & - & 3 & 30 & 2 & 20 & - & - \\
\hline Zaki Biam & 10 & 100 & 3 & 30 & 2 & 20 & - & - & - & - \\
\hline Ugba & 10 & 100 & 3 & 30 & - & - & 2 & 20 & - & - \\
\hline Buruku & 10 & 100 & 4 & 40 & 2 & 20 & & & 2 & 20 \\
\hline Tse-Agberagba & 10 & 100 & 4 & 40 & 2 & 20 & 1 & 10 & - & - \\
\hline Aliade & 10 & 100 & 3 & 30 & - & - & 1 & 10 & 2 & 20 \\
\hline Naka & 10 & 100 & 3 & 30 & 3 & 30 & 2 & 20 & - & - \\
\hline Ugbokpo & 10 & 100 & - & - & 3 & 30 & 3 & 30 & - & - \\
\hline Obagaji & 10 & 100 & 2 & 20 & 3 & 30 & - & - & - & - \\
\hline Idekpa & 10 & 100 & 4 & 40 & 2 & 20 & - & - & - & - \\
\hline Otukpa & 10 & 100 & 3 & 30 & - & - & 1 & 10 & - & - \\
\hline Okpoga & 10 & 100 & 5 & 50 & 2 & 20 & - & - & 1 & 10 \\
\hline Otukpo & 10 & 100 & 5 & 50 & 1 & 10 & - & - & 2 & 20 \\
\hline Igumale & 10 & 100 & 3 & 30 & 1 & 10 & 1 & 10 & - & - \\
\hline Oju & 10 & 100 & 3 & 30 & 2 & 20 & - & - & - & - \\
\hline Obarike Ito & 10 & 100 & 3 & 30 & 2 & 20 & 3 & 30 & - & - \\
\hline Makurdi & 10 & 100 & - & - & 3 & 30 & - & - & 2 & 20 \\
\hline Gbajimba & 10 & 100 & 4 & 40 & 3 & 30 & 2 & 20 & - & - \\
\hline Obode Obi Ijegwu & 10 & 100 & 3 & 30 & - & - & 1 & 10 & - & - \\
\hline Ainu & & & & & & & & & & \\
\hline Daudu & 10 & 100 & 5 & 50 & - & - & 2 & 20 & - & - \\
\hline
\end{tabular}

Meloid = Meloidogyne Prat $=$ Pratylenchus Roty $=$ Rotylenchulus Freq. $=$ Frequency

\section{REFERENCES}

1. Acosta N, Ayala A (1975). Pathogenecity of Pratylenchus coffeae, Scutellonema bradys, Meloidogyne incognita and Rotylenchulus reniformis on Dioscorea rotundata. J. Nematol. 7: 1-6.

2. Adesiyan SO, Odihirin RA (1977). Plant-parasitic nematodes associated with yam tubers in Mid-West State, Nigeria. Nig. J. Plant Prot. 3:171-179.

3. Adegbite AA, Adesiyan, SO, Agbaje GO, Omoloye AA (2005). Host suitability of crops under yam intercrop to root-knot nematode (Meloidogyne incognita Race 2) in South-Western Nigeria. J. Agric. Rural Develop. Trop. Subtrop. 106: 113-118.

4. Afolami Steven, Solomon Sunday and Daramola Fisayo (2014). Biodiversity of plant-parasitic nematodes of sugarcane in Bacita, Nigeria. Journal of Entomology and Nematology vol. 6, Pp. 71-79

5. Afolami S. O. (2000). Suggestions for the improvement of current methods of studying and reporting resistance to root-knot nematodes. International Journal of Nematology 10: 94-100.

6. Agbaje GO, Adegbite AA, Akinlosotu TA (2003). Performance of new hybrid yam (D. rotundata Poir) varieties in the forest zone of Nigeria. Tropicultura 21: 149-152.

7. Agbaje GO, Adegbite AA, Akinlosotu TA, Shoyinka SA (2002). Performance of new hybrid yam varieties ( $D$. rotundata Poir) under different cropping systems. Afr. J. Root and Tuber Crops 5: 8-11.

8. Ayala A, Acosta N (1971). Observations on Yam ( $D$. alata) nematodes. Nematropica 1: 39-40.

9. Bond J P, McGawley E C and Hoy J H. (2000). Distribution of plant parasitic nematodes on sugarecane in Louisiana and efficiency of nematicides. Supplement to the Journal of Nematology 32:493-501.

10. Bridge J (1972). Nematode problems with yams. Dioscorea spp. in Nigeria. Pest Articles and News summaries 18:89-91

11. Bridge, J. (1973). Nematodes of pests of yams in Nigeria. Mededelingen Faculteit Landbouw wetenschappen Gent 38, 841-852

12. Bridge, J., Price, N. S. and Kofi, P. (1995). Plant parasitic nematodes of plantains and other crops in Cameroon, West Africa. Fundamental and Applied Nematology 18, 251-260.

13. Bridge, J., Hunt, D. J., and Hunt, P. (1996). Plant parasitic nematodes of crops in Belize. Nematropical 26, 111-119.

14. Caveness FE (1982). Plant parasitic nematodes and IITA mandate food crops: A position paper. IITA, Ibadan, Nigeria. p.15.

15. Caveness, F. E. 1975. A simple siphon method for separating nematodes from excess water. Nematropica 5:30-32

16. Coyne DL, Kolombia YA, Kariuki G, Luambano N, Bert W, (2006). First report of dry rot disease of yam 
caused by Scutellonema bradys in East Africa. Plant Disease, 100:1794. http://apsjournals. apsnet. org/loi/pdis

17. Doncaster C C. (1962). A counting dish for nematodes. Nematologica 7:33-336

18. EPPO, (2014). PQR database. Paris, France: European and Mediterranean Plant Protection Organization. http://www. eppo. int/DATABASES/pqr/pqr. htm

19. FAOSTAT data (2004). Food and Agriculture Organization of the United Nations, Rome.

20. Gao, O. K. (1992). The observation of occurrence of root-knot nematodes on Chinese yam. Chinese vegetables 5, 24-25

21. Green KR, Florini DA (1996). Pests and Pathogens of Yams in Storage. A meeting report. Afr. J. Root and Tuber Crops 1:38-42.

22. Mai W F and Lyon H H. (1975). Pictoral key to Genera of Plant-parasitic nematodes, 4th Edition. Cornerstone Publishing Associates. A Division of Cornell University Press, pp.219.

23. Hahn SK, Isoba JCG, Ikotun T (1989). Resistance Breeding in Root and Tuber crops at the IITA, Ibadan, Nigeria. Crop Protect. 8:147-168.

24. Michel LUC, Richard A S and Bridge J. (2005). Plant Parasitic Nematodes in Subtropical and Tropical Agriculture. 2nd Edition. 493-520.
25. Mohandas, C. and Ramakrishnan, S. (eds) (1997). Pathogenic effect of root-knot nematodes, Meloidogyne incognita on African white yam, Dioscorea rotundata. Indian Journal of Nematology 27, 233-236.

26. Nweke FI, Ugwu BO, Asadu CLA, Ay P (1991). Production costs in the yam-based cropping systems of south-western Nigeria. Research Monograph No. 6, IITA, Ibadan, Nigeria. Resource and Crop Management Division. p.29.

27. Ricka DA, Barker KR (1992). Nematode Assays and Advisory Services. In: Nematology in the Southern Region of the United States R. D. Riggs (Ed) South Cooperative Service Bulletin 276 Arkansas Agric. Exp. Fayetteville, Arkansas. pp. 8-20.

28. Schenck S and Holtzmann O. (1990). Evaluation of Potential Problems in a changing Agricultural systems: Nematodes control in Hawaiian crops. Plant Diseases 1990. Pp 837-839

29. Taylor (1971). Annual Report Bacita, Nigeria

30. Thompson AK, Been BO, Perkins C (1973). Nematodes in Stored Yams. Exp. Agric. 9: 281-286.

31. Whitehead A. F and Hemning J R. (1965). A comparison of some quantitative methods of extracting semi veriform nematodes from soil. Annals of Applied Biology 55:25-28. 